\title{
JOURNAL.RU
}

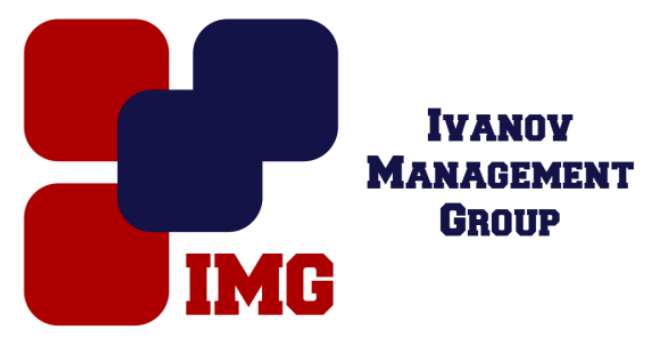

Галушко И.Г., Галушко А.В., Маркувинас И.В.

Кубанский государственный университет Краснодар, Россия

doi: 10.18411/lj-30-06-2017-41

idsp 000001:1j-30-06-2017-41

\section{Педагогическое общение как фактор эмоционального благополучия ребенка}

\section{Аннотация}

Данный статья посвящена влиянию педагогического общения на эмоциональное благополучие детей. Сфера общения - самый мощный источник, который определяет психическое развитие и становление человека как личности. Благодаря наблюдениям можно прийти к выводам о том, что выбор жизненного пути ребенка во многом зависит от позиций педагога и методов его преподавания. Тип общения взрослого с ребенком, главным образом влияет на детское развитие.

Ключевые слова: общение, развитие, влияние, педагог, воспитание, формирование, обучение.

Педагогическое общение - некая связь педагога с учениками в учебновоспитательной деятельности. Она нацелена на формировании подходящего психологического климата, который положительно сказывается на эмоциональном состоянии ребенка, а также его интеллектуальном развитии. Основные правила педагогического общения:

- Проявлять педагогический такт.

- Уметь: устанавливать связь с детьми; проникаться их состоянием и поддерживать при любых обстоятельствах; сохранять положительный эмоциональный тон, сопровождающийся мимикой пантомимикой; жестикуляцией и 
разговорной

речью

привлекать

К

себе

собеседника(общедоступность,

выразительность,

последовательность, краткость); слушать с интересом и почтением; никак не останавливать собеседника; обладать ораторскими данными (тон, дикция, произношение);

- Уметь: распоряжаться собственными эмоциями (выталкивание негативных помыслов из головы); установка на позитивное восприятие собеседника; обладать способами поддержания эмоционального благосостояние детей, так как это сказывается на их работоспособности. Значимым фактором формирования психологического благосостояния считается необходимость создания благоприятного климата.

От персоны преподавателя и его мер воздействия на ребенка зависят конечные результаты воспитательного процесса. В ходе общения с чадом старшие обязаны не просто на теоретическом уровне делиться с ребятами собственным опытом и знаниями, а являться настоящим эталоном для подражания.

Настоящее педагогическое общение подразумевает субъектные взаимоотношения: партнеры в результате общения создают определенную связь, которая характеризуется наличием уважения и понимания у обеих сторон по отношению друг к другу. Если в общении преподавателя с ребенком отсутствует взаимная направленность т. е. дети здесь являются лишь объектом воздействия, то в таком случае невозможно сказать о полноценном общении. От поведения педагога зависит его дальнейшее взаимодействие с воспитанниками, которое оказывает большое влияние на развитие самосознания детей, на их взаимоотношения и коммуникабельность.

Главной задачей общения выступает стремление преподавателя гарантировать ребятам ощущение эмоциональной безопасности, доверия к обществу. Истинный педагог не должен оценивать развитие детей по конкретным образцам и критериям. Он учитывает личностные особенности каждого ребенка, стремится создать благоприятные условия для всестороннего развития. Ребенку предоставляется определенная самостоятельность, его активность не подавляется.Не спроста опытнейшие педагоги как можно больше времени проводят с детьми. Они, подготавливаясь к уроку, воспитательному мероприятию, празднику подробно продумывают каждую организаторскую деталь: не просто план проведения мероприятия, а то - с кем кого посадить, 
например, чтобы каждый чувствовал себя комфортно. Общение на досуге, на занятии, во внеклассной работе является важным условием развития учебновоспитательного процесса, а также стимулом для дальнейшего развития.

Именно поэтому в общении педагога с детьми необходимо использовать крайнюю осторожность в подборе ни только манеры общения, но и формы обращения. Такой вид общения должен отличаться некой легкостью и непринужденностью. Особое внимание необходимо уделять деткам дошкольного возраста, так как именно они нуждаются в обучении, которое направлено на постановку правильной речи и общения.

Педагог является для детей неким спутником, который всегда укажет верну дорогу и отведет от бед. Кроме того, педагогу необходимо постоянно учиться, развиваться и познавать этот мир во всех его проявлениях. Ведь чему может научить человек, который сам не придерживается определенных правил и установок? Так, что роль педагога требует полной самоотдачи, непрерывного саморазвития, открытости и такта. При наличии этих качеств, педагог становится для детей настоящим маяком, ориентиром в этом мире, о котором они вспоминают с теплые долгие годы.

\section{$* * *$}

1. Лобанова, Е.А. Дошкольная педагогика: учебно-методическое пособие. Николаев, 2005.

2. Сластенин, В.А. и др. Педагогика: Учеб. пособие для студ. высш. пед. учеб. заведений. М.: Академия,

3. Столяренко, Л.Д. Педагогическое общение. Ростов: Феникс, 2004.

4. Толочек, В.А. Стили профессиональной деятельности. М.: Смысл, 2000. 